\title{
Hong Kong, An Urban Future Shaped by Rail Transport
}

The next phase in Hong Kong's development: improving connections to Shenzhen and Guangdong Province

\section{Corinne Tiry}

\section{OpenEdition}

\section{Journals}

Édition électronique

URL : http://journals.openedition.org/chinaperspectives/647

DOI : 10.4000/chinaperspectives.647

ISSN : 1996-4617

Éditeur

Centre d'étude français sur la Chine contemporaine

Édition imprimée

Date de publication : 1 octobre 2003

ISSN : 2070-3449

Référence électronique

Corinne Tiry, « Hong Kong, An Urban Future Shaped by Rail Transport », China Perspectives [En ligne],

49 | september-october 2003, mis en ligne le 17 janvier 2007, consulté le 10 décembre 2020. URL :

http://journals.openedition.org/chinaperspectives/647 ; DOl : https://doi.org/10.4000/ chinaperspectives.647

Ce document a été généré automatiquement le 10 décembre 2020.

(c) All rights reserved 


\section{Hong Kong, An Urban Future Shaped by Rail Transport}

The next phase in Hong Kong's development: improving connections to Shenzhen and Guangdong Province

\section{Corinne Tiry}

\section{NOTE DE L'ÉDITEUR}

Translated from the French original by Peter Brown

1 The harbour city of Hong Kong is a very circumscribed territory which, with 6.7 million residents, has one of the highest urban densities in the world ${ }^{1}$. Indeed, a forest of towers standing against the mountain is the image that comes to mind to describe the urban landscape developed there in the post-war period. Office and residential towers are, after all, the most common type of architecture, by virtue of the valuable ratio they offer in terms of construction volume to land occupied.

2 The extreme characteristics of Hong Kong immediately signal a metropolis whose transport systems have to contend with major constraints. The management of huge volumes of traffic, the need to get a return out of scarce and expensive land, and the weight of excessive centralisation have, over the past three decades, led the Hong Kong government to rethink the accessibility of its space. This complex situation, albeit one that is also a source of value added, has become of vital concern for any metropolis wishing to maintain its position as one of the world's great cities. The economic reputation and wealth of Hong Kong are derived, after all, from its global commercial exchanges and from the service sector, which alone represents $89 \%$ of its current GDP. The originality and effectiveness of the government's plans are a function of the interaction of several different levels. In Hong Kong, the modernisation of transport networks presupposes control over traffic flow at the local, regional and of course global levels all at once. In particular, we must bear in mind the fact that tourism, 
based as it is on the performance and quality of services and movements, among other things, is second only to commercial activity as a source of income for the city.

In the late 1990s, a significant amount of new transport infrastructure and facilities were put into operation, such as the international airport at Chek Lap Kok on Lantau Island, the multi-modal railway station in Kowloon, and the Tsing Ma bridge, with others still at the planning stage. One remarkable thing is that the relocation of the international airport from the city centre to the outskirts has brought about a reconfiguration of the urban transport network and, over time, it should have a similar effect on the urban centres too. However, beyond the modernisation of transport networks, this turn-around brings new opportunities to the city, both through the regeneration of land (230 hectares of vacant airport land to be recovered ${ }^{2}$ and urban growth (increased density of the new transport nodes, additional land reclaimed from the sea). The government and transport operators have, in tandem, managed to take hold of this situation in a clear-sighted way, in order to make Hong Kong into a twentyfirst century metropolis ${ }^{3}$.

4 For one thing, the creation of Chek Lap Kok airport is accompanied by several major rail and motorway infrastructure projects in order to establish smooth and rapid connections between this international gateway and the city centre. Further, a series of sites connected with the new railway stations have been identified for their high urban development potential along the new link-ups. The most innovative of these developments, Tung Chung new town, originally planned to accommodate 180,000 residents ${ }^{4}$ near the airport, is a beneficiary of this new accessibility, participating in the start of a process of rebalancing of the saturated city centre westwards.

The introduction of a rapid urban transport system sees the emergence of a new type of player

5 Paradoxically, for a large city as densely populated and urbanised as Hong Kong, the rapid public transport system was developed late in comparison with other modern metropolises such as Tokyo, Paris or New York. Admittedly, Hong Kong is a younger city, and its topography imposes greater constraints. It has a much smaller area of land and $70 \%$ of its 1,100 square kilometres is mountainous terrain on which there is hardly a building. Economic activity rarely takes place outside an approximate $7.5 \mathrm{~km}$ radius of Victoria Harbour, and it is this area that constitutes the central business district (CBD). However, the uneven distribution both of economic functions and, more diffusely, of the present population across the three main inhabited areas ${ }^{5}$ shows the whole importance of linkages in the context of such discontinuous occupation of land.

6 Until the end of the 1970s, Hong Kong had $34 \mathrm{~km}$ and $16 \mathrm{~km}$ of railway lines operated respectively by two separate transport companies. They were marginalised, however, in the context of a market cornered by the many cheap private ferry and bus companies (see Table 1). The first railway line, opened in 1910 and electrified in the early 1980s, is operated by the publicly listed company Kowloon-Canton Railway (KCR, since 1982 KCR East Rail). It links the densely populated Kowloon peninsula to the Chinese border to the north by crossing through the east of the New Territories where a large number of new towns were built along the railway track after the second world war, mainly on former agricultural land. For over half a century, this line remained the sole intercity railway in the whole of the territory.

7 The second line, a tram line serving the northern coast of Hong Kong Island in which is found the business district of Central, though private, has similarly never been 
extended since its opening in 1904. The Hong Kong population had to wait until 1979 to finally get a new modern rapid transport system, the Mass Transit Railway (MTR). This was both to complement and relieve the pressure on the existing public transport system, which, whilst dense and diverse, was heavily congested.

On the eve of that key year, 6.3 million trips were being made daily on the bus, ferry, railway, tram and taxi systems. In 2001, this figure had already almost doubled to 11 million trips a day over the entire network, that itself had been increased in the last twenty years by the five subway lines of the mass transit railway (MTR). Today, while buses remain the dominant mode of public transport in Hong Kong, a little over 2.2 million passengers move around each day on the MTR network -87.7 kilometres of infrastructure and 49 railway stations. However, this impressive growth in the overall movement of people over the past two decades is to be explained also both by the sustained increase in the population ${ }^{6}$ and by the persistently very low level of car ownership among Hong Kong households ${ }^{7}$. This latter situation is a good illustration of the population's habits in terms of public transport use and takes into account the significance of the daily flow of traffic in Hong Kong.

In 1973, the Hong Kong government decided to construct a rapid public transport system to meet the challenges caused by the perennial problems of traffic congestion. Two years later, the government set up the Mass Transit Railway Corporation (MTRC), which was solely responsible for financing, building and operating the city's new subway system. As an independent public body entirely under government control before being partially privatised in 2000- and in line with the example set by the other public transport companies in Hong Kong, MTRC does not, in theory, receive any government subsidies. Nonetheless, the procedure for acquiring land -for both MTRC and KCRC - is a profitable one, in so far as land is granted by the government rather than sold at auction, as is normally the case. The self-financing of public transport without recourse to any public funds and the poor return from operating the network have led MTRC to adopt an offensive strategy. This consists in particular in making a significant profit thanks to the income derived from the company's real estate developments -either those that it has undertaken alone or jointly with other private developers - on top of or in close proximity to railway stations that it brings into existence. One advantage of increasing the density of construction around railway stations, and consequently the growth of the local residential population, delivers in return a huge and faithful patronage. This principle of self-financing has seen the status of MTRC gradually evolve and its roles diversify, from being a mere transport operator to a powerful real estate developer and now a real player in today's urban planning 8 .

Vertical cities arising from the convergence of transport and real estate development

The five new subway lines introduced between 1979 and 1998 were accompanied by a number of MTRC real estate projects. These were not only a reflection of the company's major investments, but also of the great changes in the urban structure and landscape of Hong Kong. Notwithstanding this, two distinct periods characterise these past twenty years of development, each of which has given rise to a distinct set of urban configurations. 
Tab1e 1 : Passenger Journeys (thousands) by Main Public Transport \& Company: Annual Traffic by Undertaking

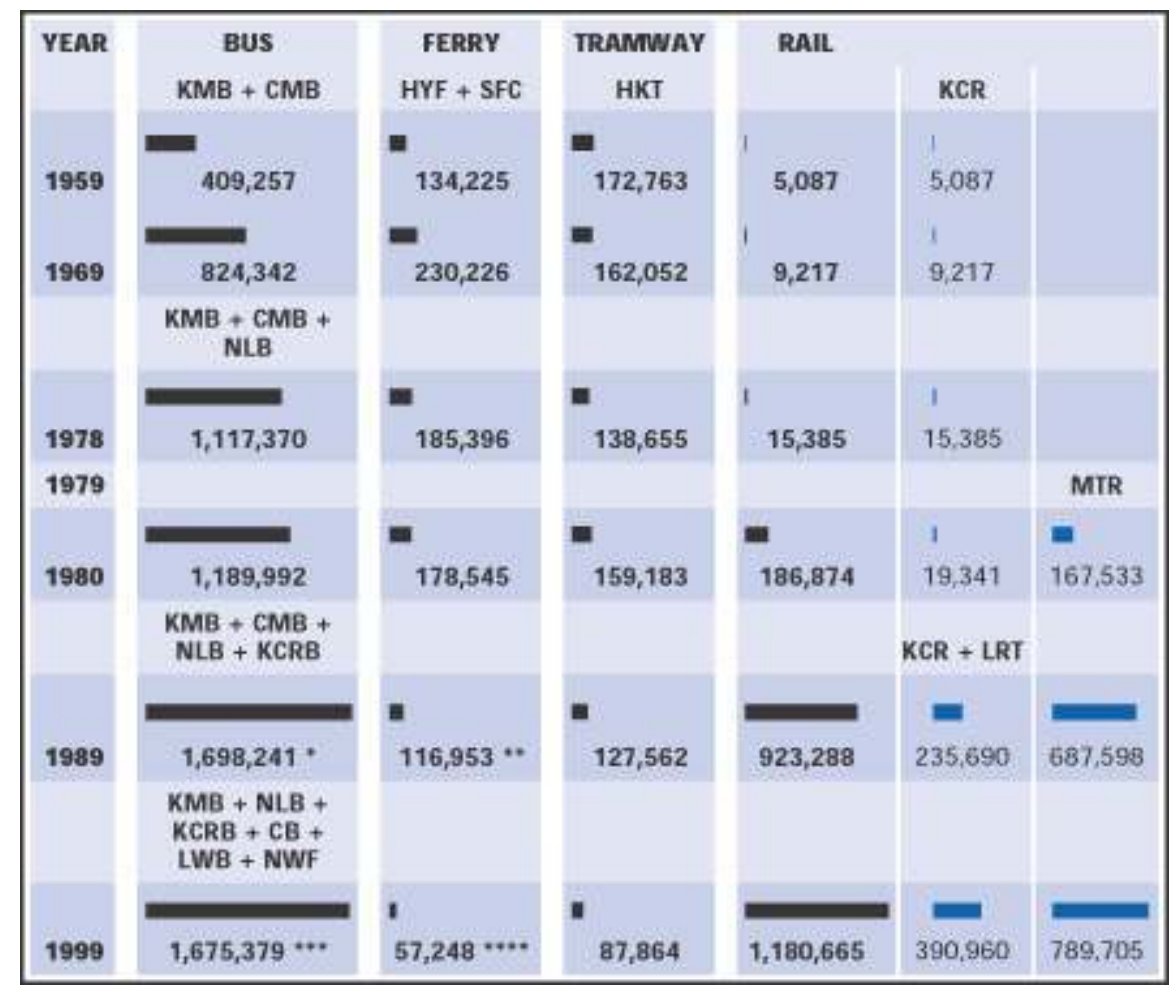

KMB: Kowloon Motor Bus. CMB: China Motor Bus. NLB: New Lantao Bus.

KCRB: Kowloon-Canton Railway Bus. CB: Citybus. LWB: Long Win Bus.

NWFB: New World First Bus.

HYF: Hong Kong and Yaumati Ferry. SF: Star Ferry.

HKT: Hong Kong Tramway.

KCR: Kowloon-Canton Railway (East Rail). LRT: Light Rail Transit.

MTR: Mass Transit Railway.

NB: For 1959 and 1969, passenger journeys represent the number of tickets sold or fares collect for single journeys and estimates of journeys made by holders of season tickets.

(*) Public Light Buses included. (**) Minor Ferries included.

$(\star \star \star)$ Red Minibus included. ( $(\star \star \star)$ Licensed Ferries Services included.

Sources: 1959 \& 1969: Hong Kong Government Press, Hong Kong Report of the Year, 1970, p. 312;

1978: Hong Kong Government Press, Hong Kong Report of the Year, 1979, p. 286; 1980: Hong Kong Government Press, Hong Kong Report of the Year, 1983, p. 309; 1989: Hong Kong Government Press, Hong Kong Report of the Year, 1992, p. 442; 1999: Transport in Hong Kong 2002, p. 35 (extracted from Chapter 14 of Hong Kong 2001).

11 Set up to serve areas that were already densely urbanised, the first three lines of the system, in the end, had only a local impact on the physical transformation of the city. The scarcity and small size of available land has resulted in real estate developments being hampered. On the other hand, this constraint relating to land has led MTRC to adopt the dual principle of concentration and mix of urban functions above or near certain railway stations. This dual principle enables the implementation of real estate projects that are necessary both for the financing of transport infrastructure and for attracting potential customers with strong requirements in terms of the provision of facilities and neighbourhood services.

In a nutshell, the principle involves erecting, on top of the railway station-more often than not an underground MTR station-, a "podium" full of shops, that can also be entered from street level. This podium is itself capped by a series of residential and/or office towers that can be reached from the commercial zone via the station or the 
street. The podium's roof is normally landscaped into a huge residents only park, which also has some community facilities and services. The podium is the hub of exchange between the various programmes in the real estate complex. Hence the station, although it is generally not visible from the outside, can be seen from the downtown area through a vertical protrusion of colossal size that is in stark contrast to the local district ones. By making vertical use of the land, MTRC creates a stratification of the various urban functions (transit, shopping, recreation, dwelling, work) usually spread out in linear fashion along the routes of communication. This configuration thereby creates something of an autonomous, vertical city.

Among the first series of "rail and urban" developments, a few exceptionally large sites such as Kowloon Bay or Tai Koo have enabled MTRC to test its model on a grand scale.

Located near the former Kai Tak airport on the first subway line (Kwun Tong Line), the urban complex of Kowloon Bay was the first major real estate project to be carried out by the company, in the early 1980s. The feat they performed was to combine a working train depot with the usual real-estate structures (railway station, shops, housing and offices) in order to maximise the return on land investment. The proximity of this large-scale area, originally devoted to train maintenance, allowed the real-estate complex to be developed overhead on a huge rectangular slab of approximately nine hectares whose support points are laid out between the railway tracks. This raised slab adjoins the station, which is at street level. The thickness of the slab, accommodating commercial facilities, forms the podium on which stand some forty residential towers as well as the company headquarters of MTR.

Another example is the urban complex of Tai Koo, located on the third subway line (Island Line) which came into service in the mid-1980s. The Tai Koo project benefited from the closure of the naval dockyards in 1987, which were on a huge tract of land. Here the form of the site allowed the development of several commercial and residential buildings on the same principle of stratification, as well as two office towers. They are all interconnected through a network of covered pedestrian bridges. The underground station remains one of the major access points to the whole complex and the podium is the place from which all kinds of traffic flow out in all directions.

Along the Island Line that crosses through the city's business district, other real estate complexes that are more focused on commercial and service sector activities have been developed on top of several railway stations (Sheung Wan, Central, Admiralty, etc).

An innovative mix of transport, real estate development and urban planning

The success of these first ventures made MTRC aware of the economic interest that a railway station can generate, even in districts that are not traditionally engaged in service sector activities, as was the case at Tai Koo or Quarry Bay.

An initial assessment was carried out in the late 1980s, at the time of the completion of the first four subway lines. As a result, MTRC undertook, in particular, to ensure better articulation of this triple functionality of the station: technical in terms of transport facilities and equipment, economic as a means of investment and financial support, and urban in so far as it acts as the focal point of the district. For the company's urban planners, while the station is a technical and economic hub first and foremost, it must also play a physical part in the structuring of the district it serves. Indeed, the generic aspect of the layering of programmes of the first generation of rail and urban complexes had a tendency to minimise the station's role as a hub of exchanges, in favour of the podium. Consequently, the specific ways in which the architects dealt 
with this were generally confined to the latter, while the railway station remained a purely technical and functional space, reduplicated each time without being given any prominence. At the time, it was even less thought of as a physically ordering urban element of the whole real estate complex. In fact, this lacuna prevented any specific character being given to any of the sites, nor full urban status, as such conferred on the railway installations. Admittedly, this initial model did its job well, but without having any clear identity, so a reassessment was undertaken.

The opportunity for the Hong Kong government to undertake major transport projects, which began in the early 1990s as a result of the planning of the relocation of the airport, enabled MTRC to launch its second generation of rail and urban developments. These took their place along the fifth and dual subway line: Airport Express Line ${ }^{9}$ and Tung Chung Line, both of which came into operation in 1998 and whose tracks run parallel to each other. This dual line was planned with two objectives in mind. First and foremost, it was designed to serve the new airport relocated outside the city centre ${ }^{10}$. Its mission was then to ease the strain on the whole of the existing transport system, that was once again at saturation point, particularly in the Kowloon area. This fifth line was conceived above all as part of an ambitious government plan for redevelopment. As such, it has to be understood as fitting into a perspective of urban development and no longer as a mere complement to the system. Indeed, like other major infrastructure or urban development projects, it is part of the ten Airport Core Programme Projects of the Hong Kong Port and Airport Development Strategy (PADS) announced in 1991. These ten projects, given impetus through the creation of the airport, and vital for the latter, are participating in the setting up of a new corridor of development towards the west of Hong Kong, an area that has been little exploited up to now but which is geographically located adjacent to the Pearl River delta.

The layout of the fifth MTR subway line (34 kilometres and seven stations) crosses through sites that are very different in nature to those of the earlier lines. These sites, little built up or land reclaimed from the sea, and earmarked for construction of the new railway stations, offer unprecedented prospects for urban development. All five of them (Hong Kong/Central, West Kowloon, Tai Kok Tsui, Tsing Yi and Tung Chung) together make up nearly 62 hectares; others are still under construction as at Penny's Bay for the opening of a Disneyland Park planned for 2005. Above all, the diversity of these areas scheduled to receive the service -ranging from the most urban on Hong Kong Island to the most intact on Lantau Island- presupposes adopting a great variety of separate solutions. Each station has its own type of architecture and urban design, specific to its particular context and capable of creating new urban focal points both locally and regionally. The mix and importance of their programmes take into account these objectives (see Table 2). While the Airport Express Line stations (Hong Kong, Kowloon, Tsing Yi, Airport) each have a unique and spectacular design, those of the Tung Chung Line (Olympic, Lai King, Tung Chung) fit into a more modestly domestic architectural mould. In any case, responsibility for the design of each station has been given to an independent architectural firm, albeit one that is guided by MTRC's prior recommendations.

Hong Kong station: a new block reflecting the hypercentre

21 Located in the heart of the CBD and having a sophisticated marine-style facade, Hong Kong station is the focal point of the new urban line. For arriving travellers, this station represents the gateway to the city, while for others it gives a foretaste of the airport 
barely 23 minutes from the central area of town. Thus the architectural language used brings together a modernity specific to large-scale facilities such as airports and financial centres. Indeed, the real estate complex of the International Finance Centre (IFC) erected on top of the railway station is composed of currently modern elements: a vast atrium for baggage registration, two office towers, a commercial podium and a hotel complete with park (still under construction). The atrium constitutes the main element of the northern façade of the complex. This huge space, which is completely glassed in on four levels, offers views over the harbour and lets in a great amount of natural light. Two IFCs, one of the two office towers, is an 88-storey skyscraper -the tallest in the city - that is set off against the existing skyline by the way it juts forth in solitary fashion and constitutes the city's new landmark. One IFC is on a permeable round podium that serves as a kind of knee-joint at the western end of the real estate complex. This open entrance hall receives the flow of pedestrians from the footbridges and then steers them to three levels of shops built on top of the railway station.

Hong Kong station, built on a relatively small plot of land (5.7 hectares) reclaimed from the sea, is also one of the most complete and complex exchange hubs of the new line. It is bordered in the north by the ferry piers, and in the south by the service sector complex of Exchange Square; it also contains a coach station and car parks. A network of pedestrian bridges winds its way through the complex and then into the whole of Central district, while a wide tunnel with moving sidewalks links them underground. The easy access of Hong Kong station is related not only to the many physical connections (overhead, underground and street level), but also to the visual ones (verticality, transparency, etc.) established with the surrounding urban fabric. This station-building opens up in three dimensions and creates an urban topography befitting the lack of relief of the artificial ground from which it emerges.

Kowloon railway station in the heart of a city of the future ${ }^{11}$

Located on the southwestern flank of the Kowloon peninsular, opposite the CBD, Kowloon railway station is the largest on the new line. It is also the linchpin of an enormous exercise in town planning that will take shape in several stages over 13.5 of the 334 hectares of land reclaimed from the water. This project represents the culmination of the principle of stratification of urban functions first tried by MTRC twenty years earlier. The main idea consists in combining an absolute separation of motorised and pedestrian traffic with mobile and sedentary activities, thanks to an interface that shapes the proportions of the site. This is given concrete form by an urban pedestrian platform built 18 metres above the ground, the centre of which is occupied by the station. All the programmes that are static in nature (flats, offices and hotels) can be accessed from the platform, while all the functions with a dynamic character (transportation, commerce) are concentrated below. The singular emergence of the station's roofing, which allows the great depth of the entrance hall to be lit with natural light, offers a gateway to this massive and compact pedestal. The station, set off by a vast mineral public space, is positioned in such a way as to ensure the main exchanges between above and below, thereby fully playing its part as pivot. Similarly, the absence of any construction above the railway right-of-way affords a visual axis from one end of the site to the other that determines the distribution of buildings and movements on the urban platform.

The podium consolidates all the infrastructure and facilities of the various modes of transport on three separate levels (two at basement level and one at street level). For 
pedestrians, there is a dense concentration on the first and second floors of a network of shopping arcades, squares and footbridges connected to the small surrounding blocks. Arranged in a vast open and landscaped space, the urban platform is set out in such a way as to offer views over the harbour. A few office towers and hotels stand near the middle, while the residential towers are laid out around the rim, to the east of the main axis. Freed from the height constraints previously imposed due to the proximity of Kai Tak airport, the site's 22 towers have an average of fifty stories. Being taller and consequently less numerous than usual, they allow more space to be freed up on the urban platform. The southwest of the real estate complex is scheduled to receive the Landmark skyscraper which will be equal in size to that of IFC One in Central, in order to complete symmetrically the image of a gateway to a renovated Victoria Harbour henceforth looking westward.

The spatial integration of Tsing Yi railway station

Tsing Yi is a small island situated between the west of the New Territories and Lantau Island, opposite one of Hong Kong's goods yards. At the time of the work on the Tsing Ma bridge and the opening of the new MTR line, Tsing Yi finds itself in a particularly favourable position since it is now linked at once to the airport, the centre of Hong Kong and the New Territories. The site identified for the new station, while relatively modest in size (5.4 hectares), was one of the most difficult to build on. The presence of the Rambler Channel along the edge of the land, where there is a lot of goods traffic, has led to the construction of a railway bridge where the two lines are built on top of each other. This bridge also passes through the real estate complex which was planned to butt up against it.

Table 2: MTRC Property Developments along the Airport Line and Tung Chung Line opened in 1998

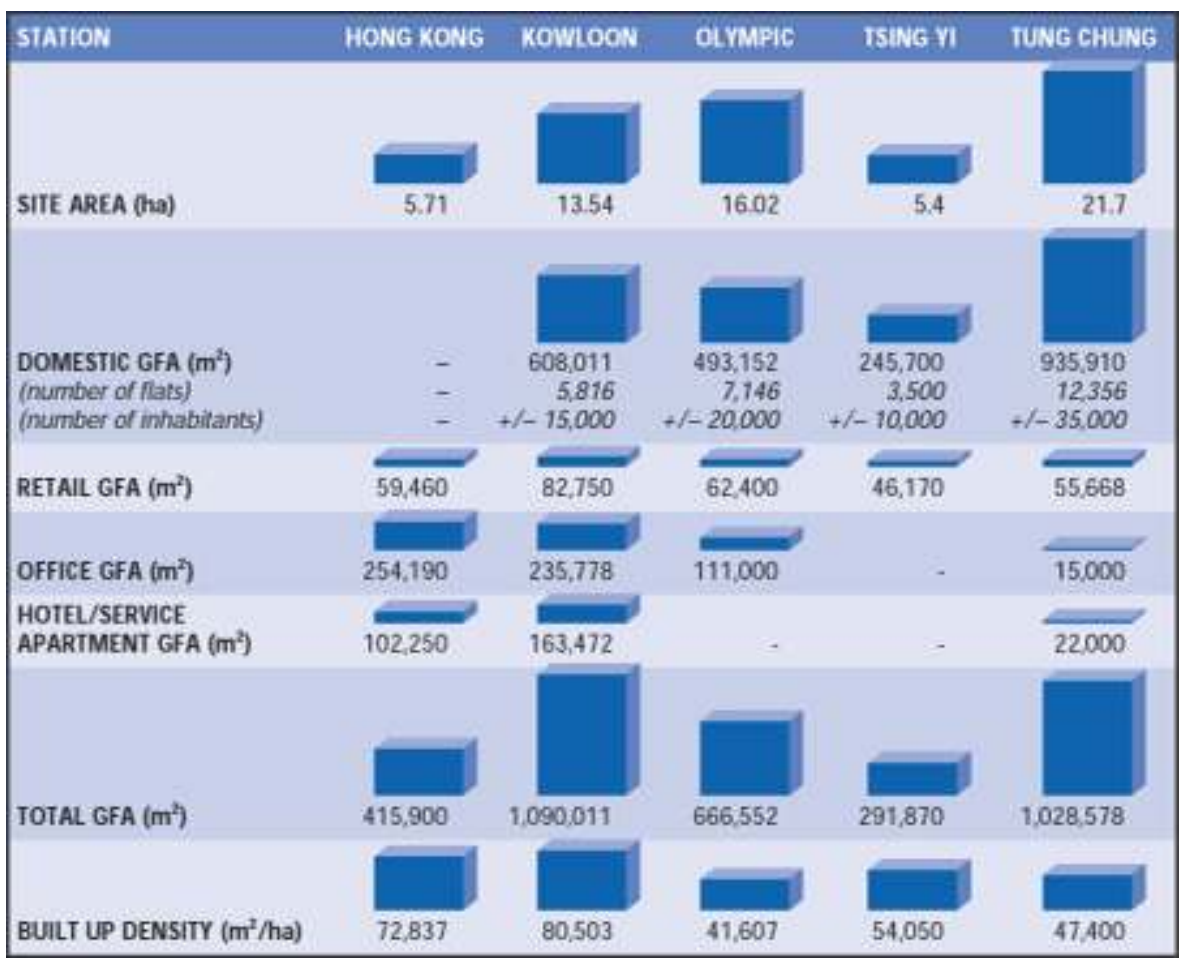

NB: GFA = Gross Floor Area

Source: MTR Corporation, Property Related Services, Hong Kong, 2002, p. 15. 
movement of trains on a higher level, that is to say across the podium, has upse the rigidity of the usual principle of the stratification of urban functions of the earlier operations. On the one hand, the creation of two enormous luminous entrance halls one for the Tung Chung Line at the first level of the podium, the other for the Airport Line two levels up- breaks the spatial monotony of the shopping arcade and fully integrates the railway station that becomes a real interior gateway. On the other hand, at the water's edge, it has been possible to convert the land, now freed of railway tracks, into a linear park offering a greater integration of the podium into the immediate space around it.

dozen residential towers housing 10,000 people in total are arranged on either side of the non-built right-of-way of the railway tracks. This undeveloped axis divides the podium's roof into two equal triangular areas and forms a visual landscaped corridor that gives a sense to the composition as a whole. To the north, the towers are implemented along the axis and are thus kept away from a noisy bypass. To the south, they form an angle that deals with the emergence of the round roof of the Airport Line's entrance hall ${ }^{12}$.

Tung Chung railway station and the primary importance of public space

Tung Chung, which was planned as a two-stage development to be able to accommodate 320,000 residents by 2011 on completion, is a new town built between the sea and the mountains. It is in easy reach of the new airport, on Lantau Island, where the vast majority of its residents work. It is also directly connected to the centre of Hong Kong.

Around twenty hectares out of an overall area of 67 hectares of land reclaimed from the sea have been set aside for the construction of the first part of the town. The railway terminal of the Tung Chung Line is the focal point of this and its construction guides the overall plan. Living five minutes walk away from the station -and consequently reducing dependence on other means of transport- was actually one of the priorities laid down jointly by the government and MTRC's planners. Many factors, such as the significant size of the land, less complicated regulations in this sparsely populated part of Hong Kong and the decision to put the train line underground, have enabled a real qualitative innovation in terms of urban planning. If some of the principles of the stratification model of urban functions still remain, the model itself is discarded in favour of a horizontal distribution of the new town's various functions. These are interconnected through vast pedestrian-only public spaces that are provided at street level. This approach is characterised by a mix of functions, a number of open spaces and a considerable amount of greenery.

The northeast/southwest orientation of the station's volume gives it a long visual corridor looking towards the rest of the new town -still under construction- along the sea-shore. The various programmes (flats, shops, some offices and a hotel) are set out along this major axis. The station is a fine rectangular shape on two levels. The trains run underground, while the street level is made up of a linear and light-filled entrance hall of a great height, that houses the usual services and small businesses to be found in a railway station. Flanked on one side by a pedestrian square and on the other by an area devoted to different forms of road transport (taxi, bus, drop-off point), the structure makes it easy to move around for pedestrians, who can use it as a simple short-cut from one side to the other. A covered but transparent pedestrian bridge crosses the station at the upper level joining a pre-existing shopping centre on the one 
side and a new-style podium on the other. The latter even has the shape of a buildingbridge so as to straddle the North Lantau Expressway -and, in parallel, the underground tracks of the Airport Line- before linking up with the raised pedestrian network of the rest of the new town. Combining shops and offices, this linear podium and its roofing arranged as a suspended garden walkway winds its way, both physically and visually, through the various parts of the town from one end to the other.

Hong Kong Current and Future Railway Network

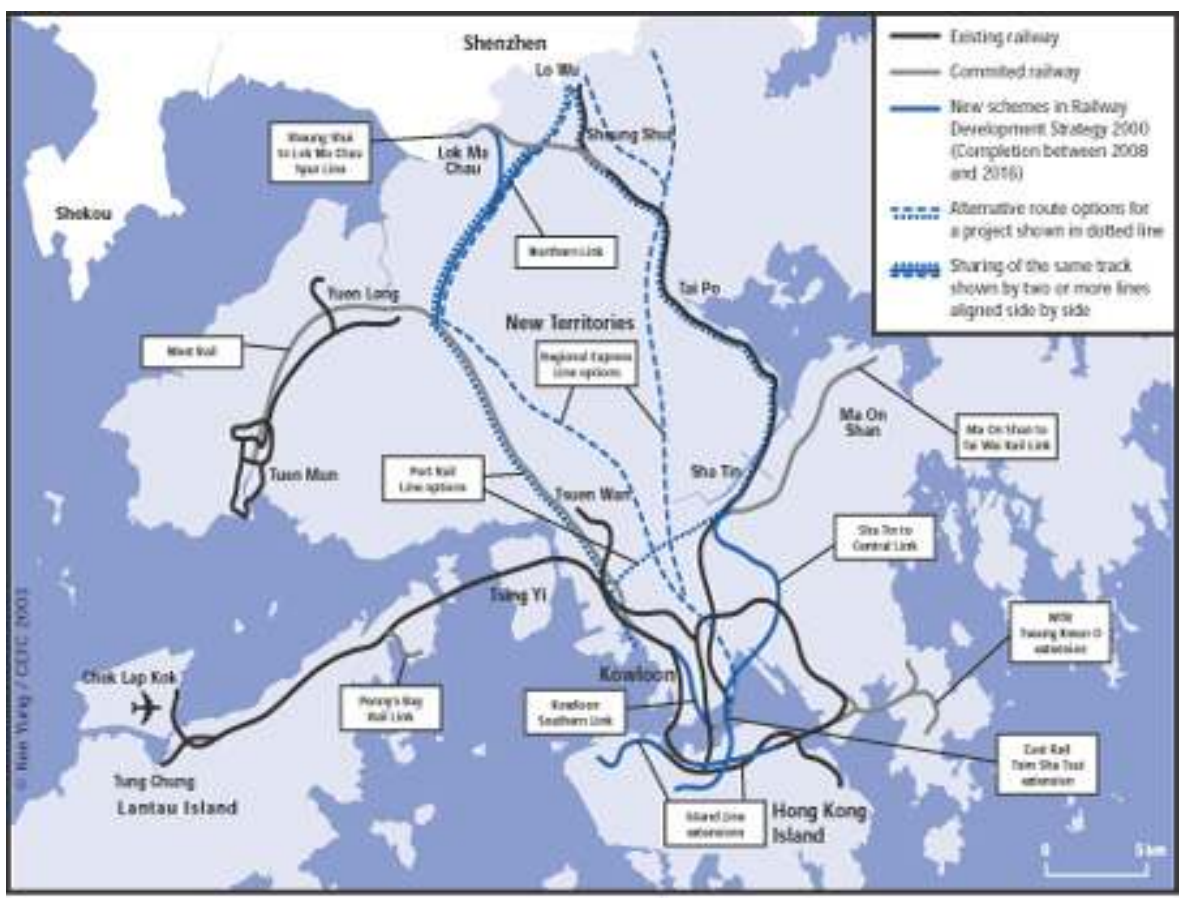

Source: Transport Bureau / Government of the Hong Kong Special Administrative Region, Transport Infrastructure Investment Opportunities in Hong Kong, October 2001.

Beyond the railway station and the podium, in the direction of the mountain, eight residential towers form a semi-circle sliced by the visual axis, stretching out from the station. Thirty metres large, this axis is given material form by a public walkway lined with greenery that connects the station square at ground level to a future park. The towers, between around thirty to fifty stories each, are built on a system of pillars varying in height from 10 metres to 16 metres. This principle of elevation above ground offers a number of advantages: giving an airiness and visual lightness to the whole real estate venture thanks to the vistas it affords, providing each flat with a broad view over the general landscape, and ensuring urban continuity by integrating the associated functions (shops and other facilities, car parks and pedestrian thoroughfares) at ground level. These are spread across a podium adapted to the general layout. Small in scale (a maximum of two levels) and with lots of roof shrubbery, its volume is broken up into two distinct parts: the commercial podium for the general public lies under the curve formed by the towers, while the podium with car parks, sports fields, gardens, etc., and reserved for residents is installed in the heart of the space shaped by the curve.

Towards a unique regional network? 
is driven by other, particularly regional, factors. The main aim of the choice of track is
to connect Hong Kong to the Special Economic Zone of Shenzhen and, in the process, to
Guangdong province. The sustained growth in the population of Hong Kong and in the transborder volume of traffic (passengers and goods) led in $2000{ }^{13}$ to the government of Hong Kong launching a vast programme to extend the two existing KCR and MTR networks) (see map). But, short of a merger between the two companies (currently being considered), MTRC's golden age could be coming to an end to the advantage of KCRC. Indeed, only 16 kilometres of extension have been allocated to the former as against 50.4 kilometres to the latter at the conclusion of the intermediate phase scheduled for 2007, whereas the Hong Kong real estate market is becoming increasingly precarious. Both the complementary nature of the networks and sources of income of the two companies - unlike MTRC, KCRC gets the major part of its income from transport- and the projected scope of the regional scheme make this a legitimate merger plan.

KCR's West Rail corridor is presented as one of the most important regional projects in so far as it will open up a second front across the border and should stimulate urban development in the northwest of the New Territories. Over time, KCRC should introduce a vast rail loop dotted with real-estate ventures and interconnections that will serve the entire territory. In some respects, this geometric figure recalls that of the Yamanote line, on a similar scale ${ }^{14}$, which skirts the centre of Tokyo. A series of more or less specialised urban centres (service sector, shops, entertainment, etc.) is concentrated at the points of interconnection with the suburban lines and give the city its particular layout. But, the sites earmarked for development by KCRC, in association with the government for the West Rail corridor, $90 \%$ of which are set down for housing, will have quite some difficulty becoming real poles of development and putting a break on the movement of people and goods, as the Hong Kong government would like ${ }^{15}$. KCRC, which is conscious of the importance of this factor requiring a new vision in terms of urban planning, is currently trying to work out a strategy ${ }^{16}$ capable of meeting this challenge.

\section{NOTES}

1. This article is the outcome of research undertaken thanks to a scholarship from the Villa Medicis Hors Les Murs Programme of the Association Française d'Action Artistique (AFAA). An earlier version was published in English in Japan Railway \& Transport Review, No. 35, 2003. The writer wishes to thank Steve Yiu, Town Planning Manager, and Kwok

China Perspectives, 49 | september-october 2003 
Yan Chan, Senior Area Project Manager (Property), of MTRC, and Alfred Yeung, Senior Manager in the Property Development Department of KCRC for their invaluable assistance.

2. By way of comparison, the Paris business district of La Défense has an area of 160 hectares.

3. On these projects being part of a structural change in Hong Kong's system of urban planning, cf. Marie Hélène Orsay-Lam, « Un aéroport et une ville nouvelle. La transformation progressive de Hong Kong au gré des enjeux globaux et locaux ", in Marie-José Roussel and Philippe Haeringer, La refondation mégapolitaine. Une nouvelle phase de l'histoire urbaine ?, Tome I : L'Eurasie post-communiste, Paris, DRAST-IRD, 2002, pp. 263-273. Also refer Vittorio Magnago Lampugnani ed., Hong Kong. The Aesthetics of Density, Munich/New York, Prestel-Verlag, 1993; Edward George Pryor ed., Hong Kong City of Vision, Hong Kong, Hinge Marketing Ltd, 1995 ; Steven Smith, Terry Farrell \& Partners: Kowloon Transport Super City, Hong Kong, Pace Publishing Ltd, 1998.

4. This population is similar to that of a city such as Lille in France, for example.

5. Hong Kong Island: $19.1 \%$, Kowloon peninsula: $29.9 \%$, The New Territories: $51 \%$.

6. About a million additional residents in each of the last few decades: 4 million in 1970, 5 million in 1980, 5.7 million in 1990, 6.8 million in 2000. Hong Kong Government Press, Hong Kong Report of the Year, 1971, 1981, 1991, 2001.

7. From 142,000 privately registered cars in 1978 to 382,000 in 2001, according to Hong Kong Government Press, Hong Kong Report of the Year, 1979, p. 286 and Transport in Hong Kong, 2002, p. 35.

8. For an overview of the evolution of MTRC's planning methods: Chris McCarthy, "The Mass Transit Railway and Urban Planning in Hong Kong: An Essential Partnership", Planning \& Development: Journal of the Hong Kong Institute of Planners, Vol. 12, No. 1, 1996, pp. 26-30.

9. The complete installation of this new line is set out by one of its designers, Alastair J. Budge-Reid, in “The Hong Kong Airport Railway”, Japan Railway \& Transport Review, No. 19, 1999, pp. 36-43.

10. On average, 25,000 passengers took it every day in 2001, according to MTRC, Annual Report 2001, Hong Kong, 2002, p. 3.

11. For a complete study of the project, cf. Steven Smith, Terry Farrell \& Partners: Kowloon Transport Super City, Hong Kong, Pace Publishing Ltd, 1998.

12. Also see Ralph Thomas, “Tsing Yi Station. State-of-the-art also complex”, Pace, Vol. 117, 1998, pp. 58-64.

13. Railway Development Strategy 2000.

14. In round figures, their north-south/east-west dimensions are of the same order: 14 $\mathrm{km} \times 7 \mathrm{~km}$ (Tokyo) and $12.5 \mathrm{~km}$ x $8.5 \mathrm{~km}$ (Hong Kong). They are close to those of the Paris ringroad (9 km x $11 \mathrm{~km})$.

15. The government's approach and planning tools are described by the director of its Planning Department, Bosco C. K. Fung, in "Planning for High-Density Development in Hong Kong", Planning and Development: Journal of the Hong Kong Institute of Planners, Vol. 17, No. 2, 2001.

16. "In summary, the KCRC intends to formulate a strategy and to develop a pattern of interconnected regional centres with integrated communities equipped with centres where social life is stimulated within a built environment with a sense of place", unpublished KCRC document. Alfred Yeung develops the idea of "linear" city in "Railway and Property Planning: A Marriage of Convenience", in Laurent Gutierrez, 
Ezio Manzini and Valérie Portefaix, HK Lab, Hong Kong, Map Book Publishers, 2002, pp. 184-195. 